\title{
MERLIN EXPRESSION IN PEDIATRIC ANAPLASTIC EPENDYMOMAS REAL TIME PCR STUDY
}

\author{
Anna Maria Buccoliero, Francesca Castiglione, and Duccio Rossi \\ Degl'Innocenti $\square \quad$ Department of Human Pathology and Oncology, University of \\ Florence, Florence, Italy
}

lacopo Sardi and Lorenzo Genitori $\square \quad$ Department of Neurosurgery, Anna Meyer Pediatric Hospital, Florence, Italy

Gian Luigi Taddei $\square \quad$ Department of Human Pathology and Oncology, University of Florence, Florence, Italy

\begin{abstract}
$\square \quad$ The most common genetic abnormalities of ependymomas involve the chromosome 22 where there is the oncosuppressor gene neurofibromin 2 (NF2). NF2 mutations are primarily encountered in spinal lesions. In contrast, NF2 alterations do not seem related to tumor grade. We studied the NF2 expression through a real-time polymerase chain reaction in 25 pediatric anaplastic ependymomas. We compared the NF2 expression in neoplastic and non-neoplastic tissues, in supratentorial and infratentorial ependymomas and in primitive and non-primitive tumors (recurrences and metastases). Statistical analysis did not prove significant differences. Our results suggest that NF2 alterations are not typical of intracranial anaplastic ependymomas.
\end{abstract}

Keywords ependymoma, anaplastic, merlin, NF2, RT-PCR

\section{INTRODUCTION}

Ependymomas account for 3-9\% of neuroepithelial tumors and are the third most common brain tumor diagnosed in children after pilocytic astrocytoma and medulloblastoma. They arise from ependymal cells lining the ventricles and the spinal canal. Little is known of the etiopathogenesis of ependymomas. An increased incidence of ependymomas, particularly spinal ependymomas, has been reported in patients affected by neurofibromatosis type 2 (NF2) syndrome. Actually, the most common genetic abnormalities of ependymomas involve the chromosome 22 where there is the

Address correspondence to Anna Maria Buccoliero, University of Florence, Department of Human Pathology and Oncology, Morgagni, 85, Florence, Italy 50134. E-mail: ambuccoliero@unifi.it 
oncosuppressor gene neurofibromin 2 (NF2). NF2 gene mutations are responsible for NF2 syndrome, which is associated with a high incidence of tumors (i.e., schwannomas, meningiomas, and ependymomas) $[10,16,19]$.

The NF2 gene encodes the production of merlin (also called schwannomin). Merlin is a member of the proteins 4.1 superfamily. Within the 4.1 superfamily, merlin shares the highest degree of homology with a subgroup of proteins including ezrin, radixin, and moesin (ERM proteins) that in polarized cells link the actin of the cytoskeleton to cell membrane glycoproteins. The similarity of merlin with the ERM proteins indicates that its function may be related to those of the ERM proteins: organization of membrane extensions and cell adhesion, membrane traffic, and cell signaling. Merlin is expressed in a variety of tissues during embryonic development and in adulthood. In the normal central nervous system, merlin is widely expressed particularly in glia and neurons [8, 22]. Several experimental data demonstrated that the merlin over-expression results in a significant decrease in cell proliferation, reversion of Ras-induced transformation, and reduced tumor formation in nude mice. On the contrary, the inactivation of the NF2 gene leads to the development of tumors through the loss of contactdependent inhibition of growth. In addition to the tumors that are classically associated with NF2 syndrome, NF2 mutations may be also found in other tumors, i.e., mesotheliomas of the lung. Furthermore, merlin expression is reduced in human malignant gliomas [4-7, 11, 12,14, 17,23, 24].

Approximately 29-38\% of ependymomas show monosomy or translocations on chromosome 2219 [3]. Among ependymomas, NF2 mutations are primarily encountered in spinal lesions. In contrast, it has been assumed that NF2 alterations do not significantly vary with tumor grade $[1,2,9,13$, $18,20,21,25]$.

In the present work, we studied the NF2 expression through a real-time polymerase chain reaction (RT-PCR) in a group of 25 pediatric intracranial anaplastic ependymomas. In addition, we compared the merlin expression in supratentorial and infratentorial ependymomas and in primitive and nonprimitive tumors (recurrences or metastases).

\section{PATIENTS AND METHODS}

\section{Patients}

Twenty-five tissue specimens were obtained from 16 consecutive patients affected by anaplastic ependymomas surgically treated at the Anna Meyer Pediatric Hospital in which fresh tumoral tissue was available for the RT-PCR. Eight $(50 \%)$ were from men and $8(50 \%)$ were from women. The average age at the time of the first surgery at our institution was 7 years (range, 1-17). (Table 1) None of the patients had clinical evidence of NF2 syndrome. 
TABLE 1 Clinical Characteristics of the Patients

\begin{tabular}{|c|c|c|c|c|c|}
\hline ID & $\mathrm{Pz}$ & Age & Sex & Tumor & \\
\hline 1 & $\mathrm{BM}$ & 11 & M & SUPRATENTORIAL & RELAPSE \\
\hline 2 & & 12 & & & RELAPSE \\
\hline 3 & & 12 & & & RELAPSE \\
\hline 4 & BA & 5 & M & SUPRATENTORIAL & RELAPSE \\
\hline 5 & & 6 & & & RELAPSE \\
\hline 6 & & 7 & & & RELAPSE \\
\hline 7 & & 9 & & & RELAPSE \\
\hline 8 & $\mathrm{CC}$ & 1 & $\mathrm{~F}$ & INFRATENTORIAL & PRIMITIVE \\
\hline 9 & $\mathrm{FaF}$ & 14 & $\mathrm{~F}$ & SUPRATENTORIAL & RELAPSE \\
\hline 10 & & 15 & & & RELAPSE \\
\hline 11 & & 15 & & & RELAPSE \\
\hline 12 & FrF & 4 & $\mathrm{~F}$ & INFRATENTORIAL & PRIMITIVE \\
\hline 13 & LM & 10 & M & SUPRATENTORIAL & PRIMITIVE \\
\hline 14 & MG & 1 & M & INFRATENTORIAL & PRIMITIVE \\
\hline 15 & & 1 & & & PRIMITIVE \\
\hline 16 & MI & 13 & M & SUPRATENTORIAL & RELAPSE \\
\hline 17 & & 13 & & & RELAPSE \\
\hline 18 & NT & 16 & M & SUPRATENTORIAL & RELAPSE \\
\hline 19 & $\mathrm{RE}$ & 5 & $\mathrm{~F}$ & INFRATENTORIAL & RELAPSE \\
\hline 20 & RA & 2 & $\mathrm{~F}$ & SUPRATENTORIAL & PRIMITIVE \\
\hline 21 & SL & 2 & M & INFRATENTORIAL & RELAPSE \\
\hline 22 & SJ & 1 & M & INFRATENTORIAL & PRIMITIVE \\
\hline 23 & GF & 4 & $\mathrm{~F}$ & INFRATENTORIAL & RELAPSE \\
\hline 24 & VCA & 1 & $\mathrm{~F}$ & INFRATENTORIAL & PRIMITIVE \\
\hline 25 & $\mathrm{ZFI}$ & 17 & M & $\begin{array}{l}\text { CAUDAL SPINAL } \\
\text { CORD }\end{array}$ & METASTASIS \\
\hline
\end{tabular}

Abbreviations: $\mathrm{ID}=$ identification number; $\mathrm{Pz}=$ patient; $\mathrm{M}=$ male; $\mathrm{F}=$ female.

\section{Methods}

Histologic diagnoses were made at the Department of Human Pathology and Oncology at the University of Florence and were performed according to the World Health Organization (WHO) criteria [16].

A series of six brain tissues obtained from six patients surgically treated because of non-neoplastic condition were used as control samples. According to institutional policies, the use of human tissue for study purposes was approved through a written informed consent.

From each fresh surgical specimen of anaplastic ependymomas, we selected a fragment macroscopically representative of the tumor. After doing so, we cut it in half: from one half several $5-\mu \mathrm{m}$ frozen sections stained with hematoxylin-eosin (H\&E) were obtained to verify the adequacy of the specimen selected for real-time presence of pathologic tissue only or nonneoplastic brain parenchyma in cases that we used as control polymerase chain reaction (PCR) the other half was immersed in ribonucleic acid (RNA) later (QIAGEN, Valencia, CA), kept overnight at $+4^{\circ} \mathrm{C}$, and finally stored at $-80^{\circ} \mathrm{C}$ until analysis. 


\section{Real-Time PCR}

The tissue (about $5 \mathrm{mg}$ ) was defrosted and cut into small pieces. The samples were resuspended in $200 \mu \mathrm{l}$ of nucleic acid purification Lysis solution (Applied Biosystems, Foster City, CA) and homogenized using tissue Lyser (Qiagen, Milan, Italy) in microcentrifuge tubes. After proteinase K digestion $\left(250 \mu \mathrm{g} / \mathrm{ml}\right.$ for $1 \mathrm{~h}$ at $\left.50^{\circ} \mathrm{C}\right)$, RNA was isolated using a 6100 Nucleic Acid Prep Station (Applied Biosystems, Foster City, CA) and successively stored at $-80^{\circ} \mathrm{C}$.

The RNA concentration and purity was quantitated spectrophotometrically by measuring their absorbance at $260 \mathrm{~nm}$ and $280 \mathrm{~nm}$. All RNA samples (200 ng) were reverse transcribed to cDNA using iScript Select cDNA Synthesis Kit (Bio-Rad Laboratories, Hercules, CA) according to the manufacturer's protocol. In the reverse transcription reaction, negative control was performed. Real-time quantitative PCR was performed on an ABI PRISM 7000 Sequence Detector System (Applied Biosystems, Foster City, CA). PCR products for NF2 were detected using gene-specific primers and probes labeled with reporter day FAM (Assay on Demand, Applied Biosystems). gAPDH was used as endogenous control gene for normalization.

PCR reactions were carried out in 96-well plate with $20 \mu \mathrm{l}$ per well using 1x TaqMan Universal PCR Master Mix. After an incubation for 2 min at $50^{\circ} \mathrm{C}$ and $10 \mathrm{~min}$ at $95^{\circ} \mathrm{C}$, the reaction continued for 50 cycles at $95^{\circ} \mathrm{C}$ for $15 \mathrm{sec}$ and $60^{\circ} \mathrm{C}$ for $1 \mathrm{~min}$.

\section{Results Analysis}

At the end of the reaction, the results were evaluated using ABI 7000 PRISM software (Applied Biosystems) and the Ct values were exported to Microsoft Excel. The $2^{-\Delta \Delta \mathrm{Ct}}$ method described by Livak and Schmittgen [15] was used to calculate fold expression levels of all 25 ependymomas relative to the average value of the six non-neoplastic specimens, of 17 non-primitive (16 recurrences and 1 metastasis), anaplastic ependymomas relative to the average value of the eight primitive anaplastic ependy-momas, and 15 supratentorial tumors relative to the average value of the eight 4 th ventricular ependymomas.

\section{Statistical Analysis}

The shift of the expression level of NF2 as estimated through relative RT-PCR was calculated according to the Kruskal-Wallis test. Data analysis was performed using the Primit statistical package, Version 3.03 (McGrawHill Inc, Milan, Italy). The AP value $\leq 0.05$ was considered to be statistically significant. 


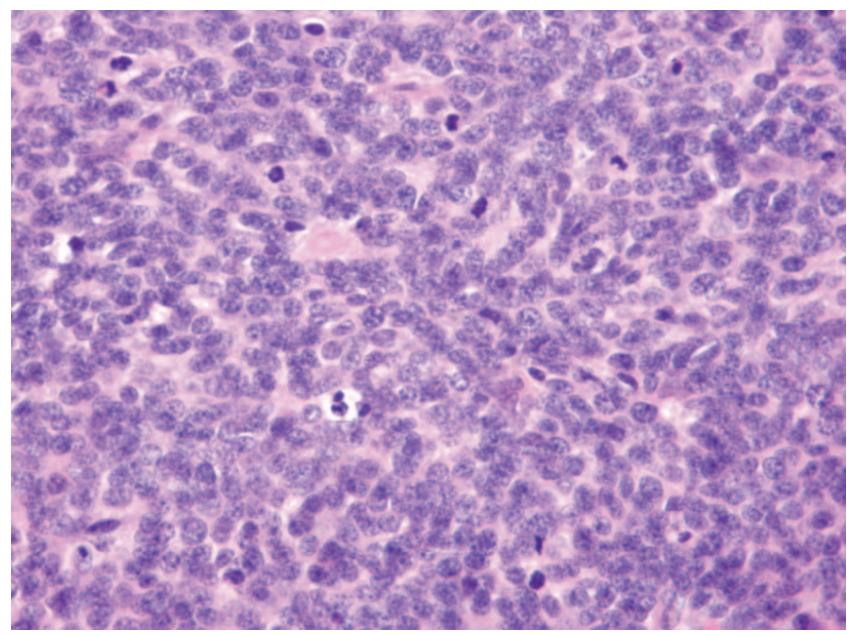

FIGURE 1 Anaplastic ependymoma (case 1) hypercellularity and numerous mitoses are appreciable. Hematoxylin-Eosin; original magnification $\times 200$.

\section{RESULTS}

Fifteen $(60 \%)$ anaplastic ependymomas were supratentorial, nine $(36 \%)$ were infratentorial, and one (4\%) was spinal. Eight (32\%) lesions were primitive tumors, $16(64 \%)$ were recurrences, and one $(4 \%)$ was a caudal spinal cord metastasis. (Table 1)

We successfully extracted RNA from all samples. NF2 gene expression was present in all ependymomas and in all six non-neoplastic brain tissues. Fifteen $(60 \%)$ tumor samples expressed the NF2 gene higher than nonneoplastic tissues $(\max 0,65$ times higher) (Table 2; Figure 2). Eight $(53 \%)$ supratentorial ependymomas expressed the NF2 gene lower than infratentorial ependymomas $(\max 0,56$ times lower). (Table 3; Figure 3). Ten $(59 \%)$ non-primitive lesions (nine recurrences and only one spinal metastasis) expressed the NF2 gene higher than primitive ependymomas $(\max 0,71$ times higher) (Table 4; Figure 4).

Statistical analysis did not establish significant differences $(\mathrm{P}>0.04)$ between non-neoplastic or neoplastic specimens, supra or infratentoria, 1 and primitive or non-primitive anaplastic ependymomas.

\section{DISCUSSION}

Ependymomas are infrequent tumors of neuroectodermal origin classifying as World Health Organization (WHO) Grades I, II, and III. Ninety percent of ependymomas are intracranial and the majority of these arise in the posterior fossa. 




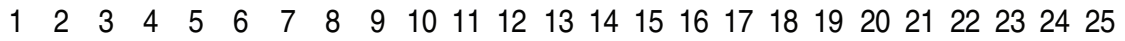

Case (the number of the lesions corresponds to the ID number of Table I)

FIGURE 2 RT-PCR merlin expression in 25 anaplastic ependymomas (reference value: mean merlin expression in 6 non neoplastic cerebral specimens). The number of the lesions corresponds to the ID number of Table 1 .

TABLE 2 RT-PCR: $\log$ RQ in 25 Anaplastic Ependymomas (Reference Value: Mean Merlin Expression in 6 Non Neoplastic Cerebral Specimens)

\begin{tabular}{rcr}
\hline ID & Pz & $\log$ RQ \\
\hline 1 & BM & 0,329284 \\
2 & & 0,652891 \\
3 & & 0,420195 \\
4 & BA & $-0,30619$ \\
5 & & 0,254628 \\
6 & & 0,055045 \\
7 & & $-0,27518$ \\
8 & CC & 0,34584 \\
9 & FaF & 0,186295 \\
10 & & $-0,09788$ \\
11 & & $-0,13039$ \\
12 & FrF & 0,382867 \\
13 & LM & $-0,00877$ \\
14 & MG & 0,286237 \\
15 & & 0,518933 \\
16 & MI & $-0,34984$ \\
17 & & $-0,52233$ \\
18 & NT & $-0,38235$ \\
19 & RE & 0,194121 \\
20 & RA & 0,058959 \\
21 & SL & 0,349152 \\
22 & SJ & $-0,60963$ \\
23 & GF & 0,083342 \\
24 & VCA & $-0,91548$ \\
25 & ZFI & 0,054744 \\
\hline & &
\end{tabular}

Abbreviations: ID = identification number; $\mathrm{Pz}=$ patient. 


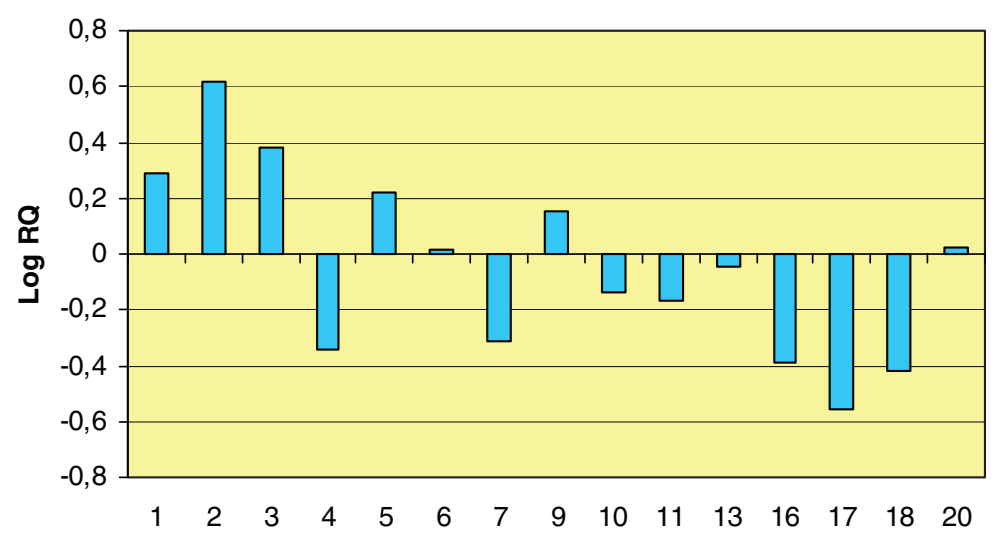

Case (the number of the lesions corresponds to the ID number of Table I)

FIGURE 3 RT-PCR merlin expression in 15 supratentorial anaplastic ependymomas (refer-ence value: mean merlin expression in 9 infratentorial anaplastic ependymomas). The number of the lesions corresponds to the ID number of Table 1.

The single most important prognostic factor is the extent of tumor resection so that ependymoma is considered a "surgical disease." In fact, the local relapses determine the majority of adverse outcomes. Nevertheless, it has been demonstrated that the histological tumor grade is also a predictor of the clinical behavior. Actually, WHO III anaplastic ependymomas show an unfavorable outcome [3].

Several molecular alterations have been reported in ependymomas, including aberrations involving chromosomes 1, 6, 7, 9, 10, 11, 12, 13, 16, 17 , and the NF2 gene on chromosome 22q12 which encodes for merlin

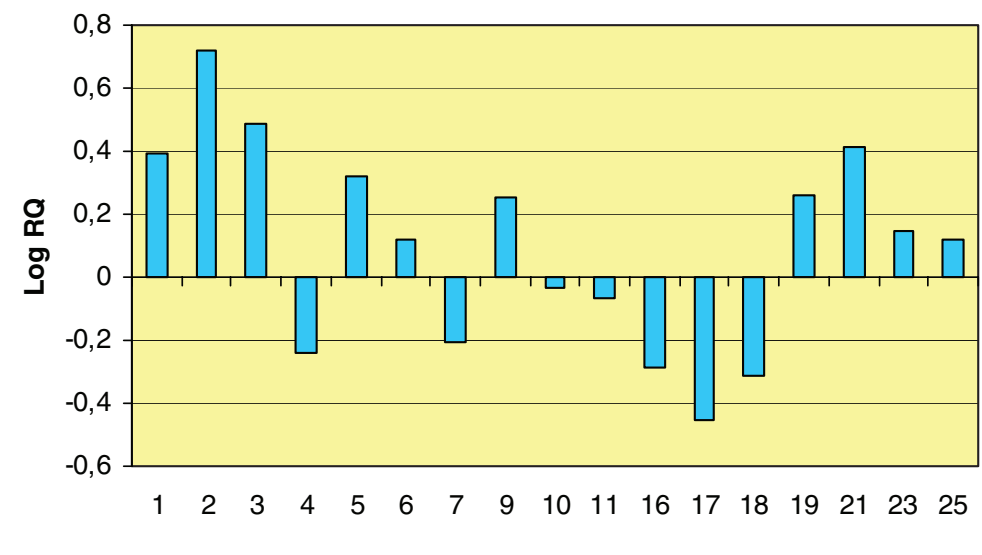

Case (the number of the lesion corresponds to the ID number of Table I)

FIGURE 4 RT-PCR merlin expression in 17 non-primitive anaplastic ependymomas-16 recurrences; 1 caudal spinal cord metastasis (reference value: mean merlin expression in 8 primitive anaplastic ependymomas). The number of the lesions corresponds to the ID number of Table 1. 
TABLE 3 RT-PCR: $\log$ RQ in 15 supratentorial anaplastic ependymomas (refer-ence value: mean merlin expression in 9 infratentorial anaplastic ependymomas)

\begin{tabular}{rrr}
\hline ID & Pz & $\log R Q$ \\
\hline 1 & BM & 0,293263 \\
2 & & 0,616871 \\
3 & & 0,384174 \\
4 & BA & $-0,34221$ \\
5 & & 0,218608 \\
6 & & 0,019025 \\
7 & & $-0,3112$ \\
9 & FaF & 0,150274 \\
10 & & $-0,1339$ \\
11 & & $-0,16641$ \\
13 & LM & $-0,04479$ \\
16 & MI & $-0,38586$ \\
17 & & $-0,55835$ \\
18 & NT & $-0,41837$ \\
20 & RA & 0,022938 \\
\hline
\end{tabular}

Abbreviations: ID = identification number; $\mathrm{Pz}=$ patient.

protein [21]. Mutations on the NF2 gene are considered the most frequent molecular alterations in ependymomas. Nevertheless, the analyses of mutations of the NF2 suppressor gene have yielded conflicting results. It has been postulated that NF2 mutations with consequent loss of merlin functions are related to spinal ependymomas only. Actually, in the opinion of some authors, spinal ependymomas could constitute a molecular variant

TABLE 4 RT-PCR: og RQ in 17 non-primitive anaplastic ependymomas-16 recurrences; one caudal spinal cord metastasis (reference value: mean merlin expression in 8 primitive anaplastic ependymomas).

\begin{tabular}{rcc}
\hline ID & Pz & $\log$ RQ \\
\hline 1 & BM & 0,394994 \\
2 & & 0,718602 \\
3 & & 0,485905 \\
4 & BA & $-0,24048$ \\
5 & & 0,320399 \\
6 & & 0,120756 \\
7 & & $-0,20947$ \\
9 & FaF & 0,252005 \\
10 & & $-0,03217$ \\
11 & & $-0,06468$ \\
16 & MI & $-0,28413$ \\
17 & & $-0,45662$ \\
18 & NT & $-0,31664$ \\
19 & RE & 0,259832 \\
21 & SL & 0,414862 \\
23 & GF & 0,149053 \\
25 & ZFI & 0,120455 \\
\hline
\end{tabular}

Abbreviations: ID = identification number; $\mathrm{Pz}=$ patient. 
of ependymomas characterized by a high incidence of NF2 mutations. In 1994, in a group of 8 ependymomas (2 spinal and 6 intracranial; 4 WHO Grade II and 2 WHO Grade III) Rubio documented a single NF2 gene base deletion in a WHO II spinal ependymoma which also had lost the wild-type allele [20]. In 1996, Birch stated that 5 of 7 spinal ependymomas that he studied harbored mutations on the NF2 gene resulting in a truncation of the predicted protein product [2]. In 2002, Alonso stated that 1 anaplastic WHO III spinal ependymoma of her series of 7 ependimomas ( 2 spinal and 5 intracranial; 4 WHO Grade II and 3 WHO Grade III) showed mutation of the NF2 gene [1].

In our study, we compared the merlin expression in anaplastic intracranial ependymomas and in the non-neoplastic brain tissue. The observation that no significant differences in the merlin expression were found between ependymomas of our series (24 intracranial and 1 caudal cord metastasis) and non-neoplastic cerebral parenchyma might indirectly support the hypothesis that NF2 alterations are unusual in intracranial ependymomas (both infratentorial and supratentorial ependymomas as also evaluated by comparing their expression).

Furthermore, among ependymomas with NF2 alterations reported in the literature, there were a number of anaplastic ependymomas. This observation stimulates us to further exclude the possibility of a grade related phenomenon. In this regard, we confirm that modifications in the NF2 expression did not characterize anaplastic ependymomas.

On the other hand, we can also suppose that the alterations in NF2 are not more frequent in a relapsed lesion than in primary tumors. Indeed, we did not observe a significant difference in primitive and non-primitive ependymomas.

In conclusion, although the method of research that we used (evaluation of the merlin expression through RT-PCR) did not assess NF2 gene aberrations, our results may indirectly provide evidence that NF2 gene mutations do not play an important role in the aetiology and progression of intracranial anaplastic ependymomas.

\section{DECLARATION OF INTEREST}

The authors report no conflicts of interest. The authors alone are responsible for the content and writing of this article.

\section{REFERENCES}

1. Alonso ME, Bello MJ, Arjona D, Arjona D, Lomas J, de Campos JM, Isla A, Sarasa JL, Rey JA. Analysis of the NF2 gene in oligodendrogliomas and ependymomas. Cancer Genet Cytogenet 134:1-5, 2002.

2. Birch B, Johnson J, Parsa A, Desai RD, Yoon JT, Lycette CA, Li YM, Bruce JN. Frequent type 2 neurofibromatosis gene transcript mutations in sporadic intramedullary spinal cord ependymomas. Neurosurgery 39:135-140, 1996. 
3. Buccoliero AM, Castiglione F, Rossi Degl'Innocenti D, Paglierani M, Maio V, Gheri CF, Garbini F, Moncini D, Taddei A, Sardi I, Sanzo M, Giordano F, Mussa F, Genitori L, Taddei GL. O6-methylguanine-DNA-methyltransferase in recurring anaplastic ependy-momas: PCR and immunoistochemistry. J Chemotherapy 2:269-277, 2008.

4. Buccoliero AM, Castiglione F, Rossi Degl'Innocenti D, Gheri CF, Garbini F, Taddei A,Ammannati F, Mennonna P, Taddei GL. NF2 gene expression in sporadic meningiomas: relation to grades or histotypes real time-pCR study. Neuropathology 27:36-42, 2007.

5. Buccoliero AM, Gheri CF, Castiglione F, Ammannati F, Gallina P, Taddei A, Garbini F, Degl'Innocenti DR, Arganini L, Di Lorenzo N, Mennonna P, Taddei GL. Merlin expression in secretory meningiomas: Evidence of an NF2-independent pathogenesis? Immunohistochemical study. Appl Immunohistochem Mol Morphol 15:353-357, 2007.

6. Curto M, McClatchey AI. Nf2/Merlin: a coordinator of receptor signaling and intercellular contact. Br J Cancer 98:256-262, 2008.

7. Grönholm M, Teesalu T, Tyynelä J, Piltti K, Bohling T, Wartiovaara K, Vaheri A, Carpen O. Characterization of the NF2 protein merlin and the ERM protein ezrin in human, rat, and mouse central nervous system. Mol Cell Neurosci 28: 683-693, 2005.

8. Gutmann DH, Wright DE, Geist RT, Snider WD. Expression of the neurofibromatosis 3 (NF2) gene isoforms during rat embryonic development. Human Mol Genet 4:471-478, 1995.

9. Hanemann CO. magic but treatable? Tumours due to loss of merli. Brain 131;606-615, 2008.

10. Ironside JW, Moss TH, Louis DN, et al. Diagnostic Pathology of Nervous System Tumours. London: Churchill Livingstone, 2002.

11. James MF, Manchanda N, Gonzalez-Agosti C, Hartwig JH, Ramesh V. The neurofibromatosis 2 protein product merlin selectively binds F-actin but not G-actin, and stabilizes the filaments through a lateral association. Biochem J 356:377-386, 2001.

12. Kim H, Kwak NJ, Lee JY, Choi BH, Lim Y, Ko YJ, Kim YH, Huh PW, Lee KH, Rha HK, Wang YP. Merlin neutralizes the inhibitory effect of Mdm2 on p53. J Biol Chem 279:7812-7818, 2004.

13. Lamszus K, Lachenmayer L, Heinemann U, Kluwe L, Finckh U, Höppner W, Stavrou D, Fillbrandt R, Westphal M.Molecular genetic alterations on chromosome 11 and 22 in ependymomas. Int J Cancer 91:803-808, 2001.

14. Lau YI, Murray LB, Houshmandi SS, Xu Y, Gutmann DH, Yu Q. Merlin is a potent inhibitor of glioma growth. Cancer Res 68:5733-5742, 2008.

15. Livak KJ, Schmittgen TD. Analysis of relative gene expression data using real-time quantitative PCR and the 2(- $\Delta \Delta \mathrm{C}(\mathrm{T}))$ method. Methods 25;402-408, 2001.

16. Louis DN, Ohgaki H, Wiestler OD, Cavenee WK. WHO Classification of Tumours of the Central Nervous System. 4th ed. Lyon: IARC Press, 2007.

17. McClatchey AI, Giovannini M. Membrane organization and tumorigenesis-the NF2 tumor suppressor, Merlin. Genes Dev 19:2265-2277, 2005.

18. Rajaram V, Gutmann D, Prasad SK, Mansur DB, Perry A. Alterations of protein 4.1 family members in ependymomas: A study of 84 cases. Modern Pathol 18:991-997, 2005.

19. Reni M, Gatta G, Mazza E, Vecht C. Ependymona. Crit Rev Oncol Hematol 63:81-89, 2007.

20. Rubio MP, Correa KM, Ramesh V, MacCollin MM, Jacoby LB, von Deimling A, Gusella JF, Louis DN. Analysis of the neurofibromatosis 2 gene in human ependymomas and astrocytomas. Cancer Res 54:45-47, 1994.

21. Singh PK, Gutmann DH, Fuller CE, Newsham IF, Perry A. Differential involvement of protein 4.1 family members DAL-1 and NF2 in intracranial and intraspinal ependymomas. Mod Pathol 15:526-531, 2002.

22. Stemmer-Rachamimov AO, Gonzalez-Agosti C, Xu L, Burwick JA, Beauchamp R, Pinney D, Louis DN, Ramesh V. Expression of NF2-encoded merlin and related ERM family proteins in the Human central nervous system. J Neuropathol Exp Neurol 56:735-742, 1997.

23. Thurneysen C, Opitz I, Kurtz S, Weder W, Stahel RA, Felley-Bosco E. Functional inactiva-tion of NF2/merlin in human mesothelioma. Lung Cancer 64:140-147, 2009.

24. Xu HM, Gutmann DH. Merlin differentially associates with the microtubule and actin cytoskeleton. J Neurosci Res 51:403-415, 1998.

25. Yokota T, Tachizawa T, Fukino K, Teramoto A, Kouno J, Matsumoto K, Emi M. A family with spinal anaplastic ependymoma: evidence of loss of chromosome 22q in tumor. J Hum Genet 48:598-602, 2003. 